\title{
Seagrass debris as potential food source to enhance Holothuria arguinensis' growth in aquaculture
}

\author{
Jorge A. Domínguez-Godino (i) | Tamára F. Santos | Hugo Pereira | Luísa Custódio \\ Mercedes González-Wangüemert
}

CCMAR- Centro do Ciências do Mar, Universidade do Algarve, Faro, Portugal

\section{Correspondence}

Jorge A. Domínguez-Godino, CCMARCentro do Ciências do Mar, Universidade do Algarve, Gambelas, 8005-139 Faro,

Portugal.

Email: jorge.adg86@gmail.com

Funding information

Fundação para a Ciência e a Tecnologia, Grant/Award Number: CCMAR/SC/ BI/02/2016, FRH/BD/105541/2014, IF/00049/2012, IF/00998/2014, PTDC/MAR-BIO/5948/2014, PTDC/ MAR/119363/2010 and SFRH/ BPD/70689/2010

\begin{abstract}
Holothuria arguinensis aquaculture started to be developed in 2014, being the first sea cucumber species from Europe. However, some aspects of its aquaculture biotechnology, such diets, need to be assessed. This work aimed to evaluate seagrass debris of Zostera noltii and Cymodocea nodosa as food source for broodstock maintenance in tanks, during breeding periods. The given feed rations per tank were calculated as the $30 \%$ of the total sea cucumber biomass in each tank and reviewed each week. Then, feed rations of seagrass and sediment were calculated from this value, according to the following percentages: $40 \%$ sediment, $15 \%$ Z. noltii, $40 \% \mathrm{Z}$. noltii, $15 \%$ C. nodosa and $40 \%$ C. nodosa. $H$. arguinensis growth, feeding rate and nutritional value were assessed under these diets. H. arguinensis fed with $40 \%$ of $Z$. noltii showed the highest growth (specific growth rate $=0.09 \pm 0.06 \% /$ day, absolute growth rate $=0.11 \pm 0.07 \mathrm{~g} /$ day) increasing their final weight in $5.86 \pm 3.57 \%$ in 57 days. However, the individuals fed with $C$. nodosa showed a negative growth. $H$. arguinensis showed a reduction in its feeding rate as the organic matter content in the diets increased. H. arguinensis did not show any important change on proximate composition, protein, lipid, mineral contents and fatty acids profile among the feeding groups, or in comparison with the individuals collected from wild habitat. Therefore, $H$. arguinensis could be fed with Z. noltii debris during tanks maintenance along breeding period, ensuring its growth and maintaining its nutritional profile.
\end{abstract}

KEYWORDS

aquaculture, growth, Holothuria arguinensis, sea cucumber, seagrass

\section{1 | INTRODUCTION}

In the last decades, it was recorded the overexploitation of the traditional fishing grounds of sea cucumbers along the Pacific and Indian Oceans due to the increasing demand of bêche-de-mer (dried sea cucumber) by the Asiatic market (Conand, 2004; Purcell et al., 2013; Purcell, Samyn, \& Conand, 2012). Since the demand of this product exceeds its supply, there has been a continuing search of new target species from other geographical regions, being harvested more than 66 species nowadays, whose declared capture is about 93.7 million tons (FAO, 2014; Purcell, 2010; Purcell et al., 2013, 2012). Additionally, the aquaculture development of the depleted species has become an important source to supply the high demand from Asiatic markets and a profitable industry with a total production of 90.4 million tonnes (US\$ 144.4 billion; FAO, 2014; Purcell et al., 2013).

Sea cucumber commercial fisheries in the Mediterranean Sea started in 1996 in Turkey, mainly focused on Parastichopus regalis 
as 'by catch' and later Holothuria polii, H. tubulosa and H. mammata; however, the target species have been changing along the last years (González-Wangüemert, Aydin, \& Conand, 2014; GonzálezWangüemert, Domínguez-Godino, \& Cánovas, 2018; M. Aydin, personal Communication). Due to the heavy fishing pressure, the first insight of their overexploitation has been found, with reduction in the largest and heaviest individuals, loss of genetic diversity and reduction in catches (González-Wangüemert et al., 2014; González-Wangüemert, Valente, \& Aydin, 2015, 2018). Similar overexploitation insight has been found on $P$. regalis fisheries in Catalonia (NE Spain; Maggi \& González-Wangüemert, 2015). Additionally to the commercial fisheries, there is a high incidence of illegal fishing of sea cucumbers in the Mediterranean and NE Atlantic waters (Domínguez-Godino \& González-Wangüemert, 2018a; GonzálezWangüemert et al., 2018). H. arguinensis is the better-reported case of illegal fishing along all its geographical distribution, finding its first insight of overexploitation at Ria Formosa (S Portugal; González-Wangüemert et al., 2018). The incidence of illegal fishing on $\mathrm{H}$. arguinensis is driven by the high prices that this species reaches in the market, which can be up to $350 € / \mathrm{kg}$ (Domínguez-Godino \& González-Wangüemert, 2018a; González-Wangüemert et al., 2018).

Under this scenario of overexploitation, illegal fisheries, high demand and high economic value of the North-Eastern Atlantic and Mediterranean Sea cucumber species, there has been a development of the aquaculture for some of new target species, which includes, for example, $H$. arguinensis (Domínguez-Godino, Slater, Hannon, \& González-Wangüemert, 2015), H. mammata (Domínguez-Godino \& González-Wangüemert, 2018b), H. polii and H. tubulosa (Rakaj et al., 2017, 2018). However, only for H. arguinensis has been developed a complete biotechnological process aiming its aquaculture production. In 2014, it was successfully induced to spawn, their embryonic and larval development described, and the first juveniles obtained (DomínguezGodino et al., 2015). From that year, the juveniles' production has exponentially grown (Domínguez-Godino \& González-Wangüemert, 2017a). For this species, the optimal stocking density and critical biomass have been also determined and its co-culture with the green macroalgae Ulva lactuca and the purple sea urchin Paracentrotus lividus assessed (in review a; Domínguez-Godino \& González-Wangüemert, 2017b). Additionally, the genetic diversity of broodstock and of the different larvae stages has been studied (González-Wangüemert \& Domínguez-Godino, 2017). In spite of all this information, there is an urgent need to assess artificial diets that ensure and enhance the $H$. arguinensis' growth, considering the total lack of knowledge on this subject. Several studies have been focused on other commercial sea cucumber species, mainly on juveniles of Apostichopus japonicus and Holothuria scabra, using dried powder of macroalgae (Chaetomorpha linum, Laminaria japonica, Sargassum thunbergii, S. Polycystum and U. lactuca), dried powered of seagrass (Zostera marina) and sea mud, with significant growth being obtained with all diets (Battaglene, Seymour, \& Ramofafia, 1999; Liu, Zhou, Yang, \& Ru, 2013; Liu, Dong, Tian, Wang, \& Gao, 2010; Song, Xu, Zhou, Lin, \& Yang, 2017; Xia et al., 2012; Zhu et al., 2007). For A. japonicus were initially formulated feeding diets based on S.thunbergii and S. polycystum, macroalgae that seems to enhance growth of this sea cucumber species in comparison with the other assessed macroalgae and seagrass species (Liu et al., 2013, 2010; Song et al., 2017; Xia et al., 2012; Zhu et al., 2007). However, these diets depend on the wild production of the macroalgae species, and therefore, it was reaching their overexploitation when the aquaculture production of $A$. japonicus grew, becoming a very expensive formulated feeding (Xia et al., 2012). On this way, there was a need to assess new artificial feeding diets based on other macroalgae and seagrass species inhabiting with $A$. japonicus.

$H$. arguinensis is generally associated with macroalgal beds, sandy bottoms and seagrass meadows of Z. noltii and Cymodocea nodosa in the Ria Formosa (Southern Portugal; Domínguez-Godino and GonzálezWangüemert, in review b; González-Wangüemert \& Borrero-Pérez, 2012; González-Wangüemert et al., 2013; Navarro, García-Sanz, \& Tuya, 2014; Siegenthaler, Cánovas, \& González-Wangüemert, 2015). $H$. arguinensis as a deposit feeder assimilates the organic matter, such as bacteria, microalgae and detritus (from macroalgae and seagrass) from the ingested sediment (Uthicke, 1999). Large amounts of seagrass debris can be found along the shores of the Ria Formosa, which could be used to produce formulated feed for $\mathrm{H}$. arguinensis. Therefore, the aim of this work was to assess the growth, feeding rate, proximate composition, mineral content and fatty acids profile of $H$. arguinensis adults under a tank-based experiment, using sediment (as control), dry powder of Z. noltii and C. nodosa as food sources. This is the first work assessing artificial diets performed in any North-Eastern Atlantic and Mediterranean Sea cucumber species to improve growth performance under aquaculture conditions. Results from this study will allow to stablish the baseline for the development and improvement of artificial diets for $\mathrm{H}$. arguinensis commercial production.

\section{2 | MATERIALS AND METHODS}

\section{1 | Experimental animals and rearing conditions}

Adults of $H$. arguinensis ( $n=50 ; 213.19 \mathrm{~g} \pm 9.57$, SE) were collected from Ria Formosa at Praia de Faro $\left(37^{\circ} 0^{\prime} 33.92^{\prime \prime} \mathrm{N}, 7^{\circ} 59^{\prime} 44.99^{\prime \prime} \mathrm{W}\right.$; Faro, Portugal) in April 2014. The individuals were transferred in cold boxes to the Ramalhete Marine Station and allocated into a 650-L tank. Adults were acclimated to tank conditions for a period of a week before the start of the experiment. To ensure feed during the acclimation period, the bottom of the tank was filled with natural sediment from the collection site. Flowing filtered seawater at ambient temperature, continuous aeration and natural photoperiod were used during acclimation and experimental period. Forty-eight hours before the beginning of experiment, the animals were allocated into bare tanks to allow that the gut contents were totally evacuated.

\section{2 | Experimental feed treatments}

Decaying debris of the two most common seagrasses from the Natural Park Ria Formosa, C. nodosa and Z. noltii, and sediment was 
used to feed H. arguinensis' adults every week, for two months. Decaying leaves of the seagrass debris of both species were collected from the shores at Ria Formosa, cleaned from external contaminants, such as other plants, algae, animals and/or plastics, and oven dried at $60^{\circ} \mathrm{C}$ until constant weight was obtained. Then, the seagrasses were ground to obtain a fine powder. Sediment was collected at Praia de Faro sieved and oven dried at $60^{\circ} \mathrm{C}$. The given feed rations per tank were calculated as the $30 \%$ of the total sea cucumber biomass in each tank and reviewed each week (Zamora $\&$ Jeffs, 2011). Then, feed rations of seagrass and sediment were calculated from this value, according to the following percentages: 40\% Sediment (S40), 15\% Zostera noltii (Z15), 40\% Zostera noltii (Z40), 15\% Cymodocea nodosa (15C) and 40\% Cymodocea nodosa $(40 \mathrm{C})$. The remained percentage ( $60 \%$ or $85 \%)$ was reached by addition of dry sediment. The weekly feed ration was divided into two equal portions and allocated into the tanks every two/three days. Previously to give the feed ration, water flow was cut for 15 min to allow feed deposition, which was not siphoned over the experiment.

\section{3 | Experimental design and samples collection}

The experiment was performed in a flow-through tank system, with seawater at ambient temperature and natural photoperiod. A total of 15 circular tanks ( $n=3$ per treatment) were used, with an area of $0.2 \mathrm{~m}^{2}$ each. The bottom of the tanks was filled with a thin layer $(2-3 \mathrm{~cm})$ of sediment from Praia de Faro. Previously to register the weight of sea cucumbers, the posterior part of the animals was gently squeezed, to allow expulsion of internal water and external water was dried (Sewell, 1990). Animals were grouped on 15 sets with three individuals each, showing similar mean wet weight among groups (Table 1; Kruskal-Wallis test, $\chi^{2}=0.541$, $p=1$ ). Each group was allocated randomly into an experimental tank. The weight of the sea cucumbers was recorded until the end of the experiment ( 8 weeks), as previously explained. Later, sea cucumbers were sacrificed by cold shock (Domínguez-Godino \& González-Wangüemert, 2018a), dissected and the internal organs were removed. Then, gutted weight was registered and individuals stored at $-20^{\circ} \mathrm{C}$. Initial gutted weight was estimated by using the equation obtained from final wet weight-final gutted weight relationship (Domínguez-Godino \& González-Wangüemert, 2018a; González-Wangüemert, Valente, Henriques, Domínguez-Godino, \& Serrão, 2016). In addition, three individuals were collected from the wild population previously to start the experiment (TO) and another three individuals at the end of the experiment (Tf). These individuals were dissected and stored as it was previously explained. These two groups of animals were collected to establish the nutritional profile of wild populations and to compare and assess possible changes on the biochemical composition produced by the different diets on the individuals from each experimental treatment.

Faeces produced by the sea cucumbers were collected two times per week using a spoon directly from the bottom of the experimental tanks. At the laboratory, the faeces were oven dried at $60^{\circ} \mathrm{C}$ for $48 \mathrm{hr}$ and weighted in order to estimate feeding rate since the amount of sediment ingested is approximately similar as the amount defecated (Domínguez-Godino \& González-Wangüemert, 2018a; Hammond, 1983; Yamanouti, 1939). Sea cucumbers were fed two times per week dividing into two ratios the feed amount for each diet. Seawater temperature was measured every day using the temperature data loggers ( $n=4$, allocated randomly).

\section{4 | Biochemical composition analysis}

The moisture content of sea cucumbers was determined by drying fresh samples at $50^{\circ} \mathrm{C}$ until to reach a constant weight. Sea cucumber bodies were freeze-dried for $48 \mathrm{hr}$. The dry samples were ground to powder, pooled together for each treatment and stored at $-20^{\circ} \mathrm{C}$ for analyses. The ash content was obtained by incineration of $0.1 \mathrm{~g}$ $( \pm 0.01)$ of sample in a muffle furnace at $525^{\circ} \mathrm{C}$ for $8 \mathrm{hr}$ (Gressler et al., 2010). The crude protein content $(\mathrm{N} \times 6.25)$ was determined by the macro-Kjeldahl method (Kjeldahl, 1883).

The total lipid content was obtained using the modified protocol of Bligh and Dyer method (Bligh \& Dyer, 1959). A mixture of methanol, chloroform and water (2:2:1) was added to $100 \mathrm{mg}$ of dry powder of sea cucumber samples and diets (sediment, $C$. nodosa and Z. noltii), which were ground with an IKA Ultra-Turrax disperser. Once the samples were homogenized, different phases

TAB LE 1 Mean values of initial gutted weight (g), final gutted weight (g), mean specific growth rate (\%/day), mean absolute growth rate ( $\mathrm{g} / \mathrm{day}$ ), mean percentage of weight change (\%) and feeding rate ( $\mathrm{g}$ ind/day) of adults of $\mathrm{H}$. arguinensis for each experimental feeding treatment

\begin{tabular}{|c|c|c|c|c|c|}
\hline & $40 S$ & $15 \mathrm{C}$ & $15 Z$ & $40 C$ & $40 Z$ \\
\hline Final gutted weight (g) & $112.36 \pm 0.55$ & $105.93 \pm 5.06$ & $111.99 \pm 4.22$ & $106.81 \pm 4.18$ & $114.95 \pm 3.62$ \\
\hline SGR (\% per day) & $0.04 \pm 0.02$ & $-0.07 \pm 0.11$ & $0.06 \pm 0.06$ & $-0.03 \pm 0.06$ & $0.09 \pm 0.06$ \\
\hline AGR (g/day) & $0.05 \pm 0.02$ & $-0.07 \pm 0.11$ & $0.06 \pm 0.07$ & $-0.03 \pm 0.07$ & $0.11 \pm 0.07$ \\
\hline
\end{tabular}

Note: Different letters within the same variable indicate significant differences, (Nemenyi post hoc, $p<.05)$. Mean \pm standard error. 
were obtained by centrifugation, and $1 \mathrm{ml}$ of the organic phase (chloroform) was transferred to a pre-weighted tube. The chloroform was totally evaporated in a block heater at $60^{\circ} \mathrm{C}$ overnight. Then, the tubes were cooled down for at least two hours in a desiccator. The tubes were weighted to estimate the total lipids by gravimetric determination.

\section{5 | Fatty acid analysis}

The fatty acid methyl ester (FAME) profile was determined using a modified protocol from Lepage and Roy (Lepage \& Roy, 1984), described in Pereira et al., 2012. Samples $(0.1 \mathrm{~g})$ of each group $(n=3)$ were added to acetyl chloride and methanol $(20: 1, v / v)$ in reaction vessels and homogenized using an IKA Ultra-Turrax during $2 \mathrm{~min}$. Then, $1 \mathrm{ml}$ of hexane was added, and the samples were heated at $100^{\circ} \mathrm{C}$ during $1 \mathrm{hr}$ in a water bath. After cooling down, $1 \mathrm{ml}$ of distilled water was added, samples were centrifuged and the organic phase removed, while the remaining water was dried with anhydrous sodium sulphate. The extracts were injected in a Varian 450-GC/240-MS (Varian 450-GasChromatograph/240-MS IT Mass Spectrometer, Varian Inc.), equipped with a BR-5MS capillary column (30 m $\times 0.25 \mathrm{~mm}$ internal diameter, $0.25 \mu \mathrm{m}$ film thickness, Bruker). FAMES were identified by comparing their retention time with those of the standards 37-FAME Mix (Supelco). Results were expressed as percentage of total fatty acids (FA).

\section{6 | Mineral composition}

For minerals determination, $100 \mathrm{mg}$ of dried samples was burned in a muffle furnace at $525^{\circ} \mathrm{C}$ for $8 \mathrm{hr}$ (Gressler et al., 2010). Then, samples were digested using hot nitric acid $\left(\mathrm{HNO}_{3}\right)$ and hydrogen peroxide. Nitric acid and the hydrogen peroxide were totally evaporated in a block heater at $110^{\circ} \mathrm{C}$, and the precipitate diluted in $5 \% \mathrm{HNO}_{3}$. Minerals were analysed by Microwave Plasma-Atomic Emission Spectrometer (MP-AES; Agilent 4200 MP-AES, Agilent).

Different concentrations of working solutions of minerals were prepared from certified standard solutions. For analytical quality accuracy, results were corrected by subtracting a blank from the analysed standard concentrations. Quantification wavelengths and calibration curves were selected to obtain the highest signal ratio and the lowest interference for the target elements. Spiking-and-recovery readings were carried out to assess validity of the results. Samples were analysed in triplicate, and results were expressed as $\mathrm{mg} / \mathrm{g}$.

\subsection{Data and statistical analysis}

The specific growth rate (SGR; Yuan et al., 2006), the absolute growth rate (AGR; Battaglene et al., 1999), the weight change (\%WC; An, Dong, \& Dong, 2007) and the feeding rate (FR; Hammond, 1983; Yamanouchi, 1939) were calculated as follows using the initial and final gutted weight:
Specific Growth Rate $(\% /$ day $)=100 *(\operatorname{LN}$ (final weight $)-L N$ (initial weight $))$ /time

Absolute Growth Rate (g/day) $=($ Final weight - Initial weight $) /$ time Weight Change $(\%)=100 *($ final weight-initial weight $)$ /initial weight $)$ Feeding Rate $(\mathrm{g}$ ind $/$ day $)=($ dry weight faeces $/$ no. sea cucumbers $) /$ time

The mean values of the growth variables, feeding rate and the nutritional values obtained were compared among treatments using Kruskal-Wallis test (Kruskal \& Wallis, 1952). The post hoc test Nemenyi was used as post hoc analyses, using the package PMCMR (Pohlert, 2014). Differences were considered significant if $p<.05$. The statistical analyses were performed in R statistic software (R Core Team, 2013).

\section{3 | RESULTS}

\subsection{Growth and feeding rates}

The mean gutted weight of the individuals at the feeding treatments of $40 \mathrm{~S}, 15 \mathrm{Z}$ and $40 \mathrm{Z}$ slightly increased by the end of the experiment, which corresponded to a percentage of weight change of $2.49 \%( \pm 1.41), 3.51 \%$ $( \pm 3.85)$ and $5.86 \%( \pm 3.57)$, respectively (Table 1; Figure 1a). However, the individuals at the feeding treatment of $15 \mathrm{C}$ and $40 \mathrm{C}$ showed a reduction in their final mean gutted weight in comparison with the initial mean gutted weight (Table 1), linked to a reduction in weight change of $-3.41 \%( \pm 5.78)$ and $-1.44 \%( \pm 3.77)$, respectively (Table 1; Figure 1a). No significant differences were found among the initial and final mean gutted weight, and for the mean weight change among feeding treatments (Table 1; Figure 1a; final mean gutted weight: Kruskal-Wallis test, $\chi^{2}=0.507, p=.973$; \%WC: Mann-Whitney, $p>$.05). Positive values of mean SGR and AGR were obtained for the individuals fed with $40 \mathrm{~S}, 15 \mathrm{Z}$ and $40 \mathrm{Z}$ (Table 1; Figure 1b, c), being the values slightly higher for the individuals at $40 Z$ feeding treatment with $0.09 \% / \mathrm{d}( \pm 0.06$; SGR) and $0.11 \mathrm{~g} / \mathrm{d}( \pm 0.07$; AGR). No significant differences were found for the mean SGR and AGR among feeding treatments (Table 1; Figure 1b,c Mann-Whitney, $p$ > .05).

The feeding rate for the individuals fed with $40 \mathrm{~S}$ diet was $19.37 \mathrm{~g}$ ind/day ( \pm 1.62$)$; this value was significantly higher than the ones obtained from the other feeding treatments (Table 1; Figure $1 \mathrm{~d}$; Kruskal-Wallis test, $p<.05)$. The individuals fed with $15 \mathrm{Z}$ and $15 \mathrm{C}$ showed similar medium values of feeding rates (Table 1; Figure 1d; Kruskal-Wallis test, $p>.05$ ), which were significantly different to the rates obtained for the other feeding treatments (Table 1; Figure 1d; Kruskal-Wallis test, $p<.05$ ). The individuals fed with $40 Z$ diet showed the lowest feeding rate, which was significantly different to the obtained ones by the individuals fed with $15 \mathrm{Z}$ and $15 \mathrm{C}$ diets, and the ones under control conditions (40S) (Table 1; Figure 1d; Kruskal-Wallis test, $p<.05$ ), but not to the feeding rate obtained for $40 \mathrm{C}$ diet (Table 1; Figure 1d; Kruskal-Wallis test, $p>$.05). 
(a)

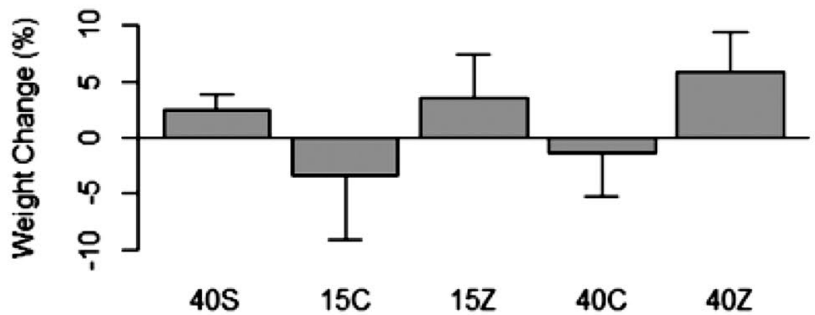

Experimental treatment

(c)

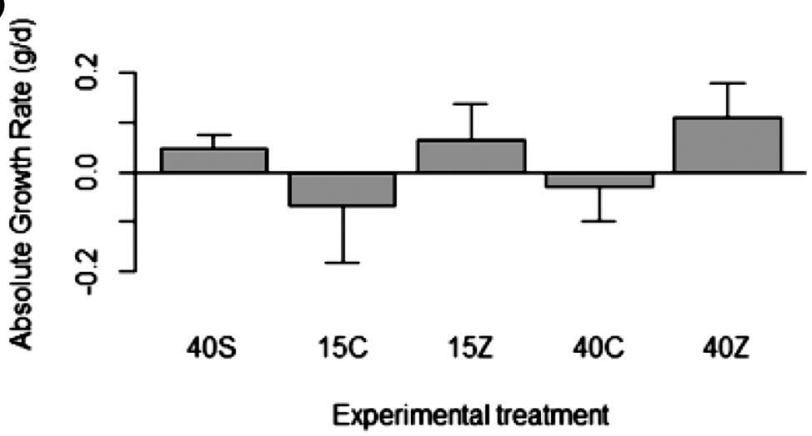

(b)

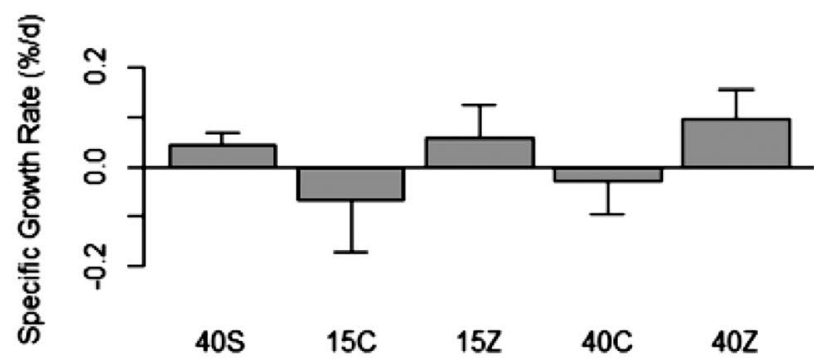

(d)

\section{Experimental treatment}

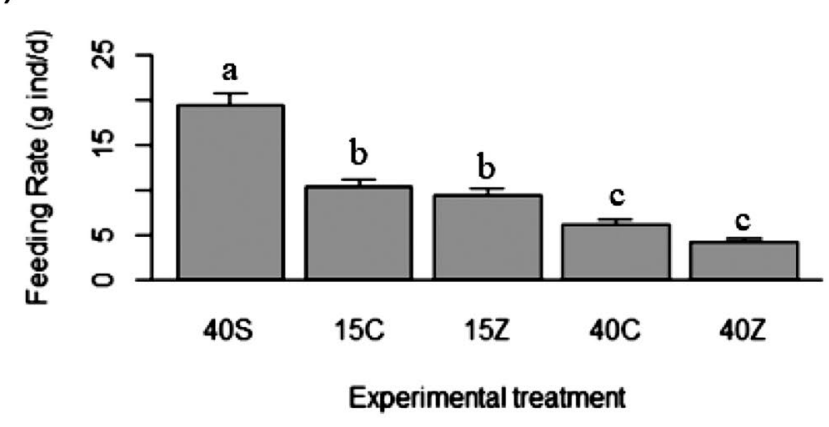

FIGURE 1 (a) Percentage of wet weight change (\%), (b) specific growth rate (\%/day), (c) absolute growth rate (g/day) and (d) feeding rate $\left(\mathrm{g}_{\text {ind }}{ }^{-1} \mathrm{day}^{-1}\right.$ ) of $H$. arguinensis individuals over eight weeks' experiment for each feeding treatment. Values are given as mean $\pm S E(n=3)$.

Different letters indicate significant differences (Nemenyi post hoc, $p<.05$ )

The seawater temperature showed a mean value of $22.22^{\circ} \mathrm{C}$ $( \pm 0.21, S D)$ during the experimental period, although it dropped to $18^{\circ} \mathrm{C}( \pm 1, S D)$ in two periods (since 24 April 2014 to 27 April 2014, and since 21 May 2017 to 25 May 2014; Figure 2). The salinity along the experiment reached a mean value of $36.66 \mathrm{ppm}( \pm 0.08, S D)$, being stable for the whole experimental duration (Figure 2).

\section{2 | Biochemical composition of $H$. arguinensis}

Animals from all the different diet treatments showed similar moisture content (\%), with a range of variation of $3 \%$ (Table 2). Individuals fed with $40 \mathrm{~S}$ had the highest moisture content, and however, it was only significantly higher than the obtained values for those fed with $40 Z$ and for individuals collected at the

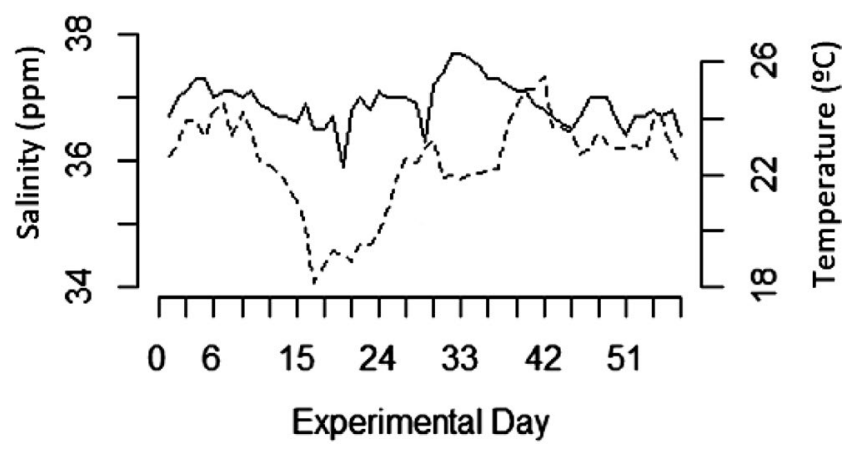

FIGURE 2 Seawater temperature (dashed line, ${ }^{\circ} \mathrm{C}$ ) and salinity (straight line, ppm) registers from the experiment experiment setup (TO), which were the ones with the lowest values of moisture content (Table 2, Kruskal-Wallis test, $p<.05$ ). The individuals fed with $15 \mathrm{Z}$ showed the highest ash content, which was significantly higher than the individuals fed with $15 \mathrm{C}$ and the individuals collected at TO, groups that again showed the lowest values of ash content (Table 2, Kruskal-Wallis test, $p<.05)$. The highest content of protein was obtained for the individuals fed with $15 \mathrm{C}$, and however, no significant differences were found among any feeding treatment and/or group of collected sea cucumbers (TO and TF; Table 2, Kruskal-Wallis test, $p>$.05). The highest total lipids content was presented by the individuals collected at TO, which was only significantly higher than the total lipids levels obtained for the individuals fed with $15 Z$ (Table 2, Kruskal-Wallis test, $p<.05$ ), group that showed the lowest value.

The individuals fed with 405 showed a lower level of protein and ash than the individuals fed with the diets based on seagrass species, except for the individuals fed with $15 \mathrm{C}$ in ash content (Table 2). However, the individuals fed with 405 presented higher level of lipids and moisture content in comparison with the other groups (Table 2).

The individuals collected at TO showed higher amount of ash, protein and lipids content than those collected at the end of the experiment (TF). However, for most of the groups fed with the different diets, the amount of ash and protein was higher and/or similar than the individuals collected at TO (Table 2). A lower lipids content was registered for all fed groups in comparison with TO (Table 2). 


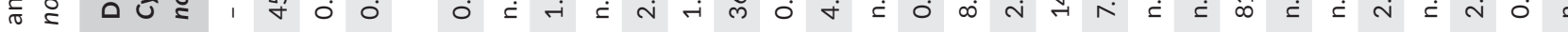

崖苋

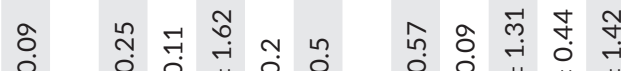

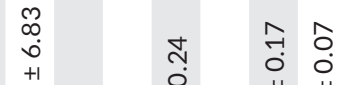

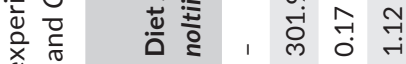

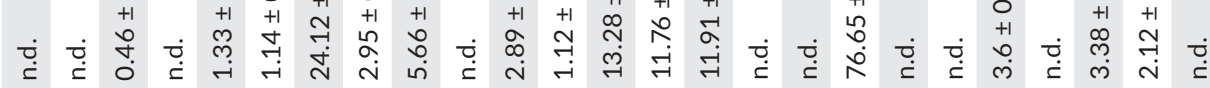

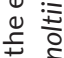

पे

ฮ

节

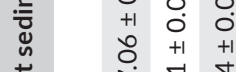

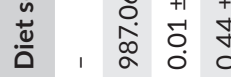

응

亏 ญ

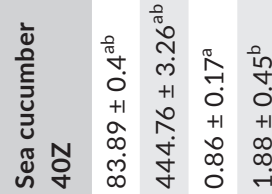

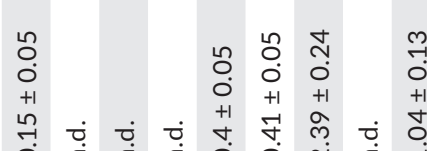

$\stackrel{\substack{m \\ m \\ 0 \\+1 \\+}}{0}$

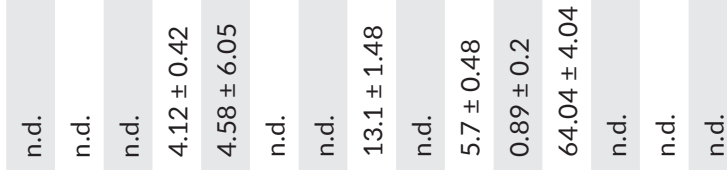

峲范

$\stackrel{0}{ \pm}$

节严

苍

늘

ఖ .

항

I

号 웡

을 을

3.

$\stackrel{0}{5}$

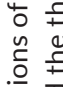

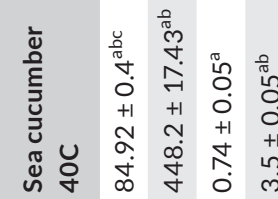

N

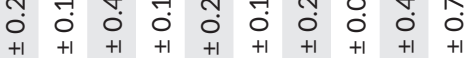

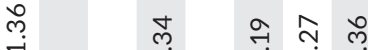

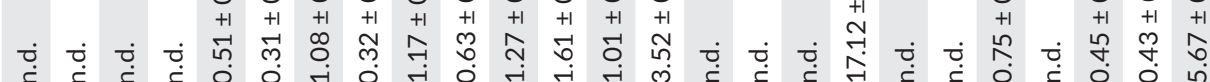

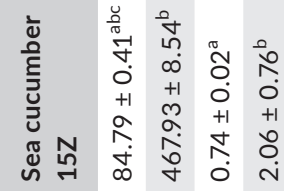

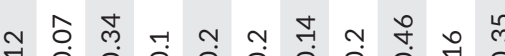

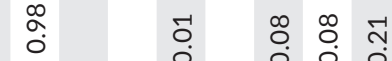

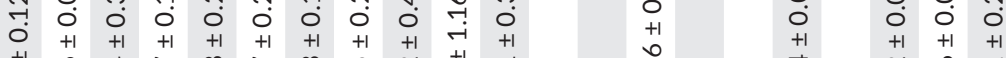

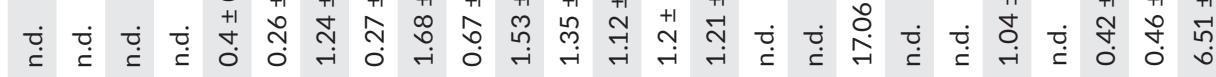

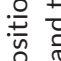

论

. $\frac{\sqrt{0}}{\sqrt{0}}$

ฮั

은 선

它

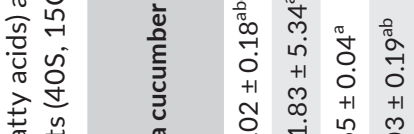

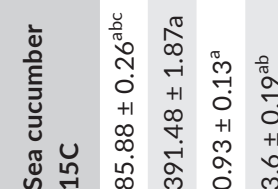

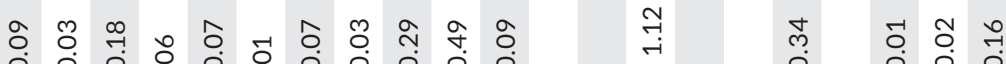

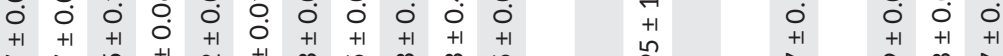

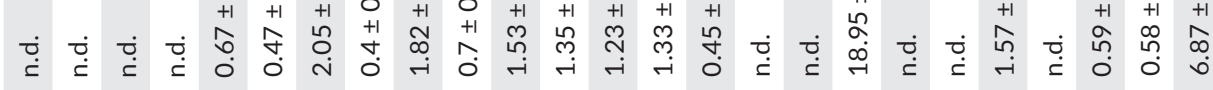

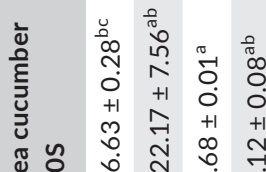

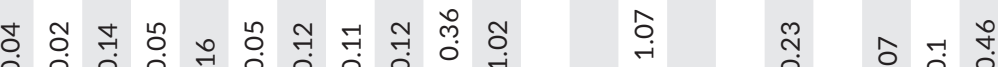

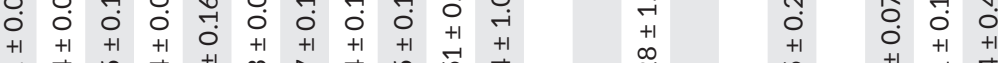

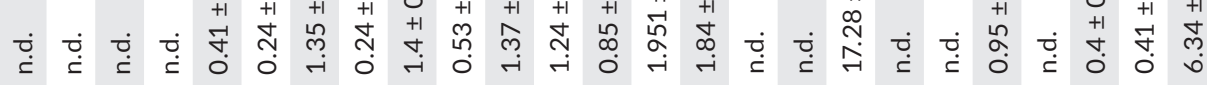

要

을

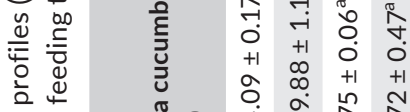

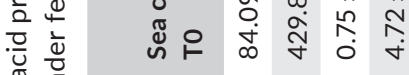

مִ

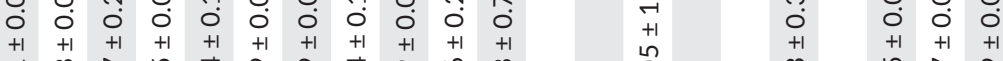

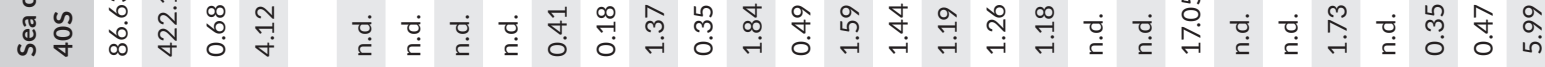

$\gg$ 峁

సี่

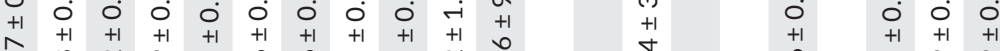

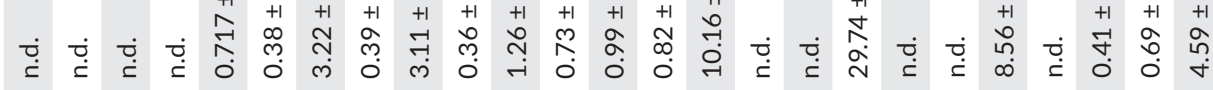

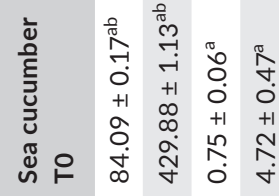

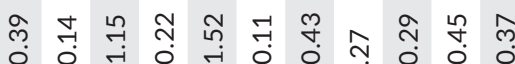

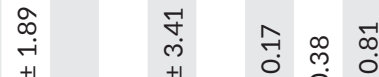

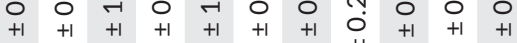

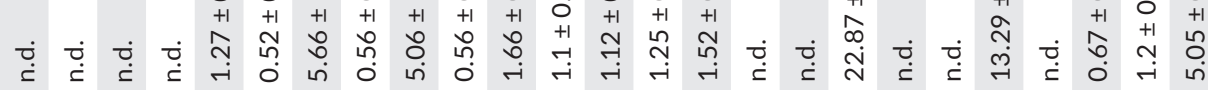

站

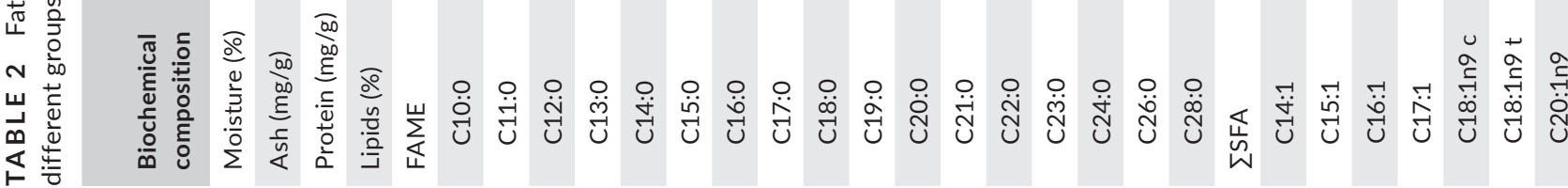




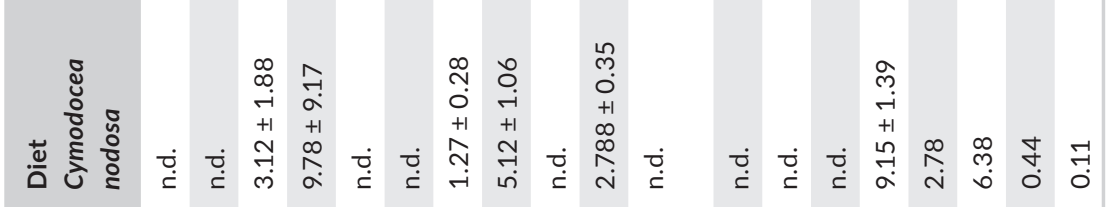

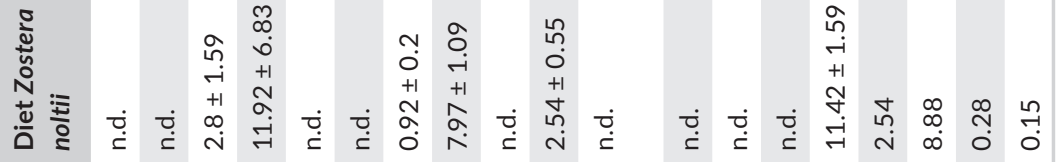

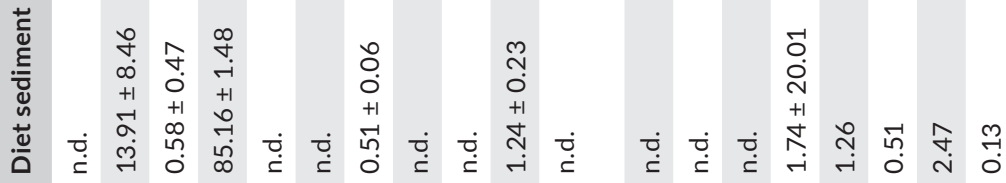

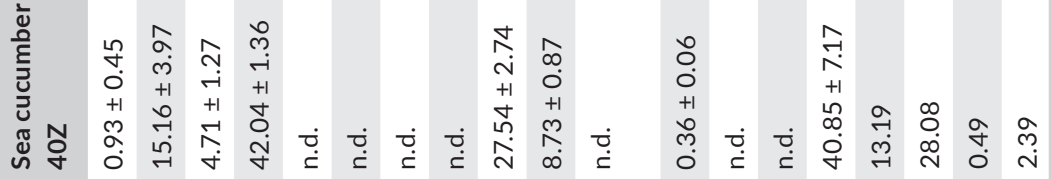

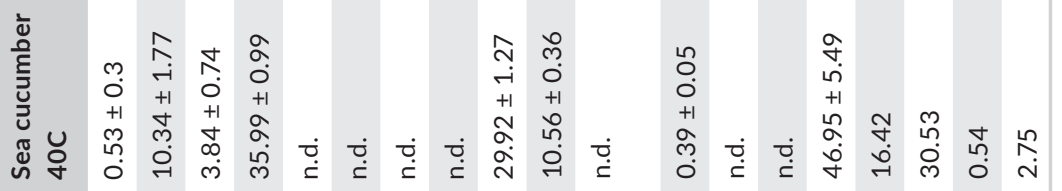

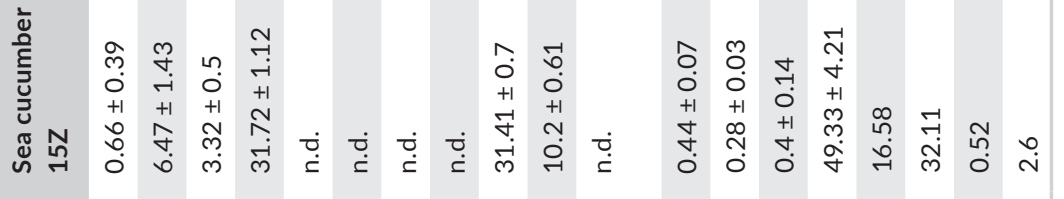

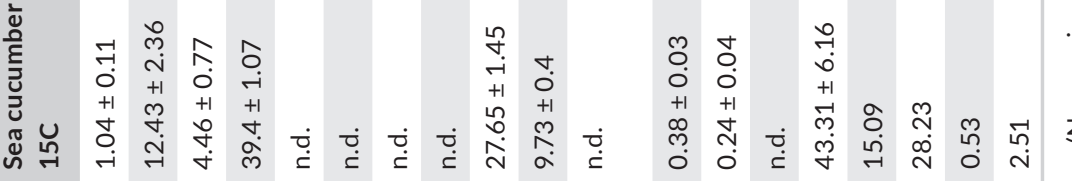

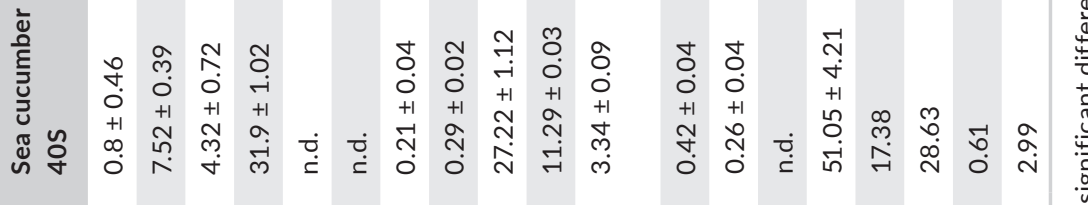

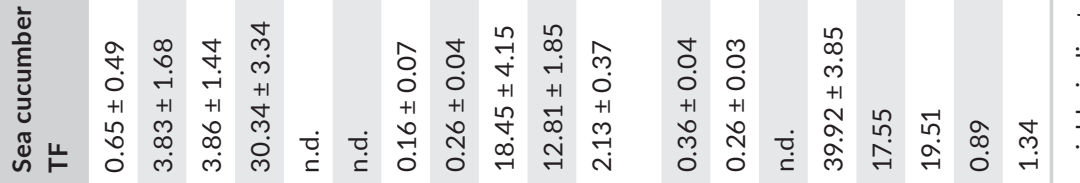

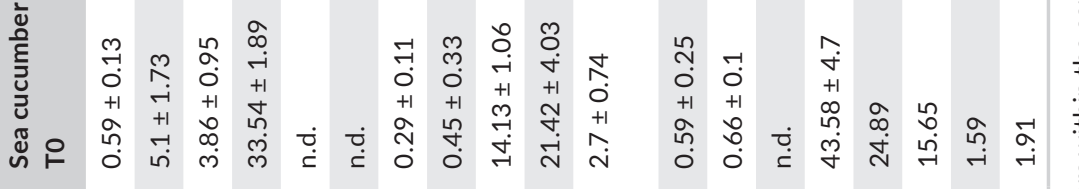

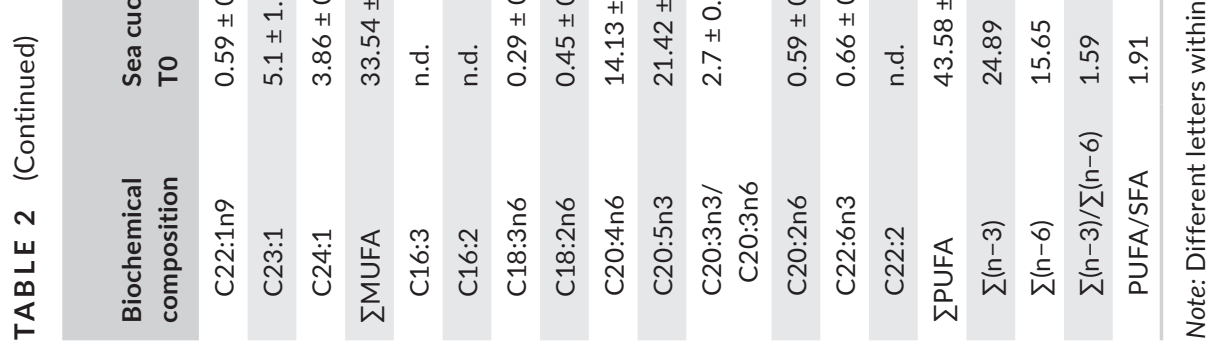




\section{3 | Mineral content of $H$. arguinensis}

$H$. arguinensis showed different proportions among analysed minerals, but any evident pattern linked with diets. $H$. arguinensis showed similar $\mathrm{Ca}, \mathrm{Mg}$ and $\mathrm{K}$ content in all the individuals fed with the different feeding treatments (Table 3). The individuals arguinensis fed with $40 \mathrm{C}$ showed the highest Na content, being only significantly different to the individuals collected at the experiment setup (TO) which had the lowest Na content (Table 3, Kruskal-Wallis test, $p<.05$ ). The individuals collected at the end of the experiment (TF) showed the highest $\mathrm{Fe}, \mathrm{Cr}$ and $\mathrm{Mn}$ content, being only significantly different to the individuals fed with $40 \mathrm{Z}$ for the $\mathrm{Fe}$ and $\mathrm{Cr}$ content and to animals fed with $40 \mathrm{C}$ for the $\mathrm{Mn}$ content; these last groups showed the lowest Fe and Mn content for $40 \mathrm{Z}$ and $40 \mathrm{C}$, respectively (Table 3, Kruskal-Wallis test, $p<.05)$. The individuals of $H$. arguinensis collected at the experiment setup (TO) showed the highest $\mathrm{Zn}$ and $\mathrm{Cu}$ content, being only significantly different to the individuals fed with $40 \mathrm{C}$ (Table 3, Kruskal-Wallis test, $p<.05$ ). The toxic minerals $\mathrm{Ni}, \mathrm{Pb}$ and $\mathrm{Cd}$ were not identified in any of the groups (Table 3 ).

\subsection{Fatty acid (FA) profiles of $H$. arguinensis}

The FA profiles of all $H$. arguinensis groups were mainly composed of arachidonic acid (ARA; C20:4n-6), 14-tricosenoic acid (C23:1), eicosapentaenoic acid (EPA; C20:5n-3), cis-11-eicosenoic acid (C20:1n9) and nervonic acid (C24:1; Table 2), which represent more than $56 \%$ of the FA content for the animals fed with the different diets, and $43 \%$ and $49 \%$ for those collected at T0 and TF, respectively. Similar amount of cis-11-eicosenoic acid (C20:1n9) and nervonic acid (C24:1) was found for all the different groups (Table 2). A slightly higher amount of eicosapentaenoic acid (EPA; C20:5n-3) was found in the individuals collected from the Ria Formosa at TF (12\%) than the individuals fed with the different diets (6\%-12\%; Table 2). However, individuals fed with the different diets showed a significant higher amount of arachidonic acid (ARA; C20:4n-6) and 14-tricosenoic acid (C23:1; $>27 \%$ and $>6 \%$, respectively) than the individuals collected at TF (18\% and 3\%, respectively; Table 2$)$. Higher amount of PUFA and MUFA (>30\%-51\%) were found in all the groups than SFA $(17 \%-$ 29\%; Table 2). The individuals fed with the different diets showed higher amount of PUFA and MUFA than the individuals collected from the Ria Formosa (TO and TF), which showed higher amount of SFA (Table 2). Therefore, these last two groups showed lower ratio PUFA/SFA (Table 2). The individuals fed with the different diets presented higher level of omega-6 FA, due mainly to ARA, than the individuals collected from the Ria Formosa (TO and TF). However, similar amounts of omega-3 FA were found for all the groups (Table 2). So, higher ratio omega-3/omega- 6 was found for these last two groups (TO and TF, Table 2).

The individuals fed with the different diets showed similar SFA (Table 2). The individuals fed with $40 \mathrm{~S}$ showed lower level of MUFA than the individuals fed with the two seagrass species, however, the $40 \mathrm{~S}$ individuals showed higher level of MUFA, therefore, the $40 \mathrm{~S}$ individual showed higher ratio PUFA/SFA (Table 2). The individuals fed with 40S showed higher level of omega-3 FA and lower/similar levels of omega-6 FA than the other feed groups, and therefore, higher ratio omega-3/omega- 6 was obtained for the 405 individuals (Table 2).

\section{4 | DISCUSSION}

$H$. arguinensis is a sea cucumber species from the North-Eastern Atlantic and SW Mediterranean that it is being exploited to supply the high demand for sea cucumbers from the Asiatic markets. In parallel to its exploitation, $H$. arguinensis' aquaculture has started to be developed, being widely improved in the last years (Domínguez et al., 2015; Domínguez-Godino \& GonzálezWangüemert, 2017a, 2018a, 2018c, in review a). Artificial diets for sea cucumber aquaculture are highly needed to ensure and improve growth rates. This is the first work in which different artificial diets were tested on $\mathrm{H}$. arguinensis aquaculture, using the two more common species of seagrass (Z. noltii and $C$. nodosa) present in the same habitats where $H$. arguinensis can be found at Ria Formosa (Domínguez-Godino and González-Wangüemert, in review b; González-Wangüemert et al., 2013; Siegenthaler et al., 2015).

In this study, the specific growth rate (SGR), absolute growth rate (AGR) and weight change for the individuals fed with the two levels of Z. noltii were slightly higher than the control animals fed with sediment, and than those ones fed with $C$. nodosa, which showed negative values for these parameters. The improvement of growth rates when $H$. arguinensis was fed with $Z$. noltii compared with the control might be due to the lower organic content and nutritional values of the sediment. In fact, this trend could be reinforced with the observation of higher improvement of growth, when the individuals were fed with the $40 \%$ of $Z$. noltii ( $40 Z$ feeding treatment). Similar results were obtained for $A$. japonicus, which showed significantly higher SGR and higher final wet weight for the individuals fed with Z. marina debris in comparison with the ones fed just with sediment (control; Liu et al., 2013). However, unexpected negative values of growth were obtained for the individuals fed with the two levels of $C$. nodosa. This result could be explained by the different microbial and microphytobenthic community linked to these seagrass species under decomposition. In fact, $H$. arguinensis along Ria Formosa is mainly associated with Z. noltii meadows, where higher densities can be found (authors observation). Therefore, $C$. nodosa under our experimental conditions was an unsuitable food source for $H$. arguinensis, which had harmful effect on the target sea cucumber species with a negative growth. In addition, it is important to take in account that deposit-feeder sea cucumbers have low cellulase activity in their guts (Yingst, 1976), and therefore, they could not digest seagrass debris which is rich in cellulose content (Z. noltii $28 \%$ and C. nodosa 45\% cellulose, Milović et al., 2017; Sèbe, Pardon, Pichavant, Grelier, \& De Jéso, 2004). Also, seagrass decomposition rate is negatively correlated to the total fibre content (Godshalk \& 


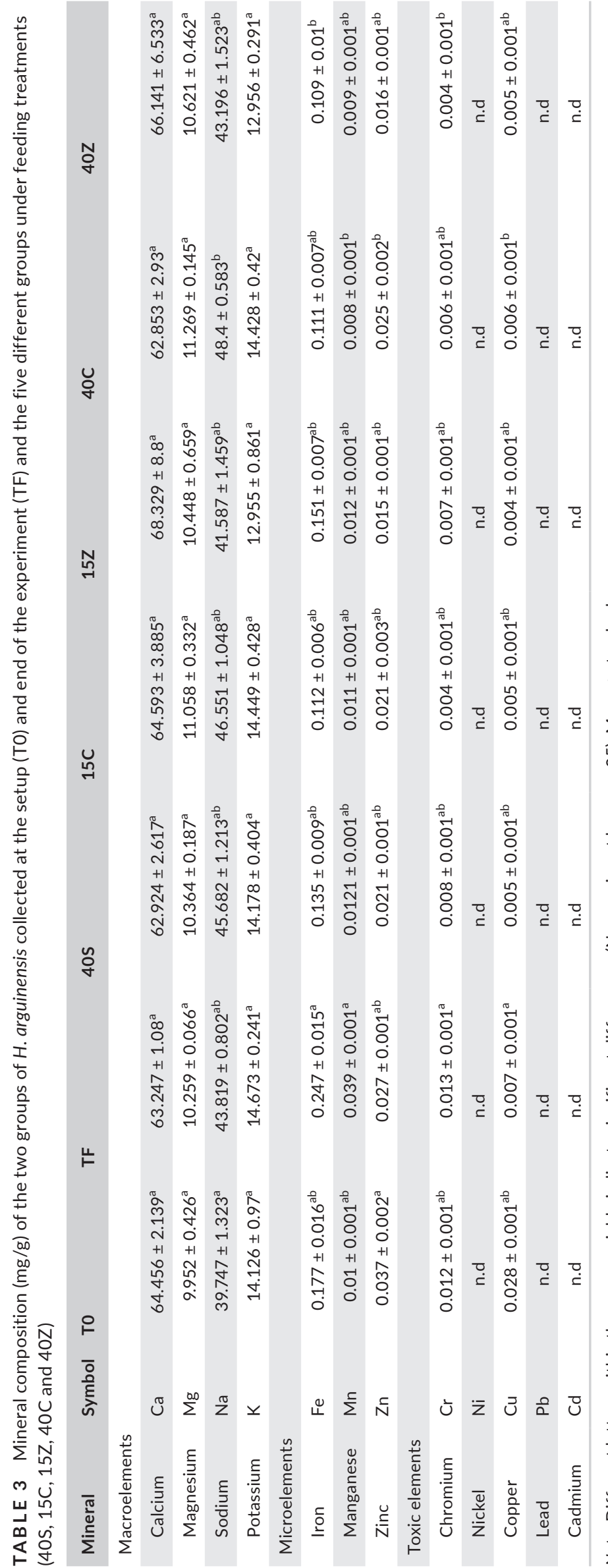


Wetzel, 1978); on this way, considering only the cellulose content of both species (Milović et al., 2017; Sèbe et al., 2004), C. nodosa would decompose slower than Z. noltii, accumulating on the sediment and not being available as food resource for sea cucumbers.

Land-based intensive culture systems in China use as optimal feed the macroalgae Sargasum polycystum or S. thunbergii for the commercial production of A. japonicus (Zhu et al., 2007). However, the use of these macroalgae relies on wild populations, therefore, with the increase in $A$. japonicus aquaculture production, there is a need to find other suitable food sources for artificial fed. Some studies have been done testing other macroalgae species, along with the seagrass $Z$. marina. For A. japonicus individuals ( $4 \mathrm{~g})$ fed with Z. marina, U. lactuca, fresh Laminaria japonica or boiled L. japonica, similar SGR values were registered, being also significantly higher than those obtained on sea cucumbers fed with S. polycystum or $S$. thunbergii (Xia et al., 2012). However, larger individuals of A. japonicus ( 31 g) showed higher SGR, apparent digestibility rate and food conversion efficiency when were fed with $S$. thunbergii, when compared with animals fed with Chatomorpha linum, Z. marina and with a mix of these last two species (Song et al., 2017). Additionally, in this last study, it was found that there was a reduction on the apparent digestibility rate and food conversion efficiency as the proportion of Z. marina increased, which could be related to the low cellulase activity of sea cucumber's guts according to the authors. The different results obtained on the same species might be due to the different nutrition requirements linked with the weight/length of individuals (Yanagisawa, 1998; Yingst, 1976).

The feeding rates obtained for the $H$. arguinensis individuals at the different feeding treatments showed a significant reduction, as the organic matter content increased on the supplied food. Additionally, when the same percentage of the seagrass species (15\% and $40 \%$ ) were used in the diets, lower feeding rates were registered on animals under $Z$. marina diets, corresponding also with a different organic matter content (301.98 and $452.62 \mathrm{mg} / \mathrm{g}$ for $Z$. marina and $C$. nodosa, respectively). This result is in accordance with sea cucumber ability to modulate their feeding activity/rate and absorption efficiency, as compensatory response to sediment quality and quantity (Roberts, Gebruk, Levin, \& Manship, 2003). Similar compensatory response has been found for $A$. japonicus (Yuan et al., 2006) and Australostichopus mollis (Zamora \& Jeffs, 2012). Generally, A. japonicus feeds on sediments containing organic matter, which includes microorganisms and the detritus of plants or animals (Song et al., 2017). According to that study, a mixture of Z. marina debris and seafloor muddy sediments with an organic content of $19.6 \%$ (ES40) could lead to a better growth on A. japonicus (Song et al., 2017).

The use of two different seagrass species debris at different proportions on diets has not changed the biochemical composition, minerals and fatty acids content of $H$. arguinensis' body wall. Similar results of lack of changes on biochemical composition and fatty acids of $A$. japonicus fed with different artificial diets, composed of seaweeds and/or terrestrial plant, were obtained previously (Seo, Shin, \& Lee, 2011; Xia et al., 2012). However, Wen et al. (2016) found changes on $A$. japonicus FAs content among the different groups fed with prepared diets: FAs were detected in high quantities in the body wall of animals fed with a single macroalgae species. However, A. japonicus' individuals fed with a mixture of different macroalgae and benthic matter showed a significant decrease of FAs level (mainly ARA; Wen et al., 2016). These individuals showed similar or elevated concentrations of EPA and docosahexaenoic acid (22:6n3 , DHA) and consequently enhanced $n-3 / n-6$ PUFAs ratios than the ones fed with single macroalgae (Wen et al., 2016). According to the authors, these results could be due to the ingestion of diatoms and dinoflagellates which are rich in EPA and DHA, respectively, and which are present in the benthic matter (Budge, Parrish, \& McKenzie, 2001; Meziane \& Tsuchiya, 2000; Wen et al., 2016; Wong, Gao, Cheung, \& Shin, 2008). In addition to the growth and feeding rates, the FAs profile confirms that $H$. arguinensis is not assimilating the different seagrass species since both presented high levels of SFA (>76\% for Z. noltii and $81 \%$ for C. nodosa) and low levels of MUFA (<12\%) and PUFA (<12\%), in contrast to $H$. arguinensis profile which is showing high level of MUFA (>30\%) and PUFA (>39\%), with low level of SFA (<19\%). H. arguinensis showed high level of ARA ( $>27 \%)$ and EPA (>8\%), which were not detected in Z. noltii or found in low proportion ( $<2.7 \%$ ) in C. nodosa. The high levels of ARA and EPA found on $H$. arguinensis could be explained by the ingestion of diatoms and other microalgae species living in the added sediment to the bottom of the tanks, species that are rich in these same FAs (Budge et al., 2001; Cañavate, 2018; Meziane \& Tsuchiya, 2000; Wong et al., 2008). As it was suggested previously, the microphytobenthic community of the sediment would have taken advantages from the seagrass decomposition (release nutrients), which could favour the microphytobenthic growth. This hypothesis could be supported by the fact that $H$. arguinensis' individuals fed with the different diets showed slightly higher PUFA and FAs (mainly ARA) than the $H$. arguinensis collected at Praia de Faro (TO and TF). The lower values obtained for $\mathrm{H}$. arguinensis at TF in comparison with the ones at TO in terms of protein, lipids and FAs could be due to the use of these components on gonad development and gamete maturation during the last period of $H$. arguinensis' gametogenic cycle (April, May and June; Marquet, Conand, Power, Canário, \& González-Wangüemert, 2017), such as it has been reported on $H$. scabra from India (Krishnan, 1968).

$H$. arguinensis did not show any significant pattern on its biochemical composition, mineral and FAs along the duration of the experiment, since similar results were obtained for the individuals collected at TO and TF, and the ones fed with the different diets. The absence of differences could be due to the short duration of the experiment and the low range of variation of seawater temperature during the experimental period. For example, moisture, carbohydrate, protein, lipid contents, total amino acids, ratios of essential amino acids, proportions of SFA and PUFA on A. japonicus showed significant seasonal variation (Gao, Xu, \& Yang, 2011). A. japonicus is a temperate sea cucumber species importantly influenced by seawater temperature; in fact, this species enters in aestivation during the summer months, when it can lose $30 \%-50 \%$ of its body mass (Liu et al., 1996; Yang et al., 2005). Therefore, this aestivation period 
is driving its changes on biochemical composition, amino acids and FAs (Gao et al., 2011). H. arguinensis could show changes on biochemical composition, amino acids and FAs along the year, because this species enters in a hibernation period during winter months with low and/or negative values of specific growth rates, which are positive and high during summer months (Domínguez-Godino \& González-Wangüemert, 2018a; Olaya-Restrepo, Erzini, \& GonzálezWangüemert, 2018). In addition, changes on lipids and protein on $H$. arguinensis could be found along the year, since it could be used for gametogenesis during winter (Marquet et al., 2017). Therefore, it could be expected to find differences on biochemical composition, amino acids and FAs among the main four seasons and not across each season and/or periods with similar environmental conditions (mainly seawater temperature and salinity), such as during our experimental period.

\section{5 | CONCLUSION}

Adults of $H$. arguinensis showed higher growth when were fed with $Z$. noltii debris than with $C$. nodosa and/or the sediment (control). However, this sea cucumber species showed negative growth when fed with $C$. nodosa, which could be due to different microphytobenthic communities growing in the sediment and/ or the different cellulose content among both seagrass species. Therefore, C. nodosa would be an unsuitable food source. $\mathrm{H}$. arguinensis, as other sea cucumbers species, modulates its feeding rate which increased as the organic matter decreased in the given food. $H$. arguinensis fed with the different seagrass species and proportions did not show significant differences on biochemical composition (proximate composition, protein, lipid and mineral contents, and fatty acids profile) and neither in comparison with the individuals collected from the natural populations (TO and/or Tf). Therefore, Z. Noltii debris could be used as food source for $\mathrm{H}$. arguinensis adults for its maintenance under tank conditions during the breeding periods.

\section{ACKNOWLEDGMENTS}

This research was supported by Fundacão para Ciência e Tecnologia (FCT, Portugal) CUMFISH project (PTDC/MAR/119363/2010; http://www.ccmar.ualg.pt/cumfish/), CUMARSUR project (PTDC/ MAR-BIO/5948/2014) and UID/Multi/04326/2019 projects. Dr. Mercedes González-Wangüemert was supported by Fundação para a Ciência e Tecnologia (FCT) postdoctoral grant (SFRH/ BPD/70689/2010) and later by FCT Investigator Programme-Career Development Contract (IF/00998/2014). Jorge Antonio DomínguezGodino was supported by Piscifactorias Albadalejo S.L and later by research fellow (CCMAR/SC/BI/02/2016) and later by the research fellow. Luísa Custódio was supported by FCT Investigator Programme (IF/00049/2012). Hugo Pereira was supported by research fellow (FRH/BD/105541/2014). Special thanks to Filipe Henriques and Sara Valente, for her help during juvenile collection and experiment activities.

\section{CONFLICTS OF INTEREST}

The authors have no conflict of interest to declare.

\section{AUTHOR'S CONTRIBUTION}

The authors contributed on the research and its publication along the study design, data analysis and paper drafting.

\section{DATA AVAILABILITY STATEMENT}

Data available on request from the authors.

\section{ORCID}

Jorge A. Domínguez-Godino (iD https://orcid.

org/0000-0001-6413-7629

Luísa Custódio (iD https://orcid.org/0000-0003-4338-7703

Mercedes González-Wangüemert (iD https://orcid.

org/0000-0002-0656-358X

\section{REFERENCES}

An, Z., Dong, Y., \& Dong, S. (2007). Temperature effects on growth-ration relationships of juvenile sea cucumber Apostichopus japonicus (Selenka). Aquaculture, 272, 644-648. https://doi.org/10.1016/j. aquaculture.2007.08.038

Battaglene, S. C., Seymour, J. E., \& Ramofafia, C. (1999). Survival and growth of cultured juvenile sea cucumbers, Holothuria scabra. Aquaculture, 178(3), 293-322. https://doi.org/10.1016/S0044-8486(99)00130-1

Bligh, E. G., \& Dyer, W. J. (1959). A rapid method for the total lipid extraction and purification. Canadian Journal of Biochemical and Physiology, 37, 911-917.

Budge, S. M., Parrish, C. C., \& McKenzie, C. H. (2001). Fatty acid composition of phytoplankton, settling particulate matter and sediments at a sheltered bivalve aquaculture site. Marine Chemistry, 76(4), 285303. https://doi.org/10.1016/S0304-4203(01)00068-8

Cañavate, J. P. (2018). Advancing assessment of marine phytoplankton community structure and nutritional value from fatty acid profiles of cultured microalgae. Reviews in Aquaculture, 11(3), 527-549. https:// doi.org/10.1111/raq.12244

Conand, C. (2004). Present status of world sea cucumber resources and utilization: An international overview. In A. Lovatelli, C. Conand, S. Purcell, S. Uthicke, J.-F. Hamel, \& A. Mercier (Eds.), Advances in sea cucumber aquaculture and management (pp. 13-23). Rome, Italy: FAO.

Domínguez-Godino, J. A., \& González-Wangüemert, M. (In review a). Let's get together! Integrated multi-trophic aquaculture of new emergent target species. Marine Environmental Research.

Domínguez-Godino, J. A., \& González-Wangüemert, M. (In review b) Habitat preference and seasonal patterns of the sea cucumber Holothuria arguinensis at Ria Formosa coastal lagoon (South Portugal). Aquatic Ecology.

Domínguez-Godino, J. A., \& González-Wangüemert, M. (2017a). Establishing the baseline of sea cucumber aquaculture in Europe. Cape Town, South Africa: World Aquaculture Society Congress. 26-30 June 2017.

Domínguez-Godino, J. A., \& González-Wangüemert, M. (2017b). Settling the baseline to co-culture the purple sea urchin Paracentrotus lividus with the sea cucumber Holothuria arguinensis. Mazatlan, Mexico: Latino American and Caribbean Aquaculture Society Congress, 7-10 November 2017

Domínguez-Godino, J. A., \& González-Wangüemert, M. (2018a). Assessment of Holothuria arguinensis feeding rate, growth and absorption efficiency under aquaculture conditions. New Zealand Journal of Marine and Freshwater Research, 53, 60-76. https://doi. org/10.1080/00288330.2018.1480499 
Domínguez-Godino, J. A., \& González-Wangüemert, M. (2018b). Breeding and larval development of Holothuria mammata, a new target species for aquaculture. Aquaculture Research, 49(4), 1430-1440. https://doi.org/10.1111/are.13597

Domínguez-Godino, J. A., \& González-Wangüemert, M. (2018c). Does space matter? Optimizing stocking density of Holothuria arguinensis and Holothuria mammata. Aquaculture Research, 49(9), 3107-3115. https://doi.org/10.1111/are.13773

Domínguez-Godino, J. A., Slater, M. J., Hannon, C., \& GonzálezWangüemert, M. (2015). A new species for sea cucumber ranching and aquaculture: Breeding and rearing of Holothuria arguinensis. Aquaculture, 438, 122-128. https://doi.org/10.1016/j.aquac ulture.2015.01.004

FAO. (2014). The state of World Fisheries and Aquaculture (pp. 223). Rome, Italy: FAO.

Gao, F., Xu, Q., \& Yang, H. (2011). Seasonal biochemical changes in composition of body wall tissues of sea cucumber Apostichopus japonicus. Chinese Journal of Oceanolgy and Limnology, 29(2), 252-260. https:// doi.org/10.1007/s00343-011-0041-7

Godshalk, G. L., \& Wetzel, R. G. (1978). Decomposition of aquatic angiosperms. II. Particulate components. Aquatic Botany, 5, 301-327. https ://doi.org/10.1016/0304-3770(78)90074-8

González-Wangüemert, M., Aydin, M., \& Conand, C. (2014). Assessment of sea cucumber populations from the Aegean Sea (Turkey): First insights to sustainable management of new fisheries. Ocean and Coastal Management, 92, 87-94. https://doi.org/10.1016/j.oceco aman.2014.02.014

González-Wangüemert, M., \& Borrero-Pérez, G. (2012). A new record of Holothuria arguinensis colonizing the Mediterranean Sea. Marine Biodiversity Records, 5, e105. https://doi.org/10.1017/S175526721 2000887

González-Wangüemert, M., Braga, T., Silva, M., Valente, S., Rodrigues, F., \& Serrao, E. (2013). Volunteer programme assesses the Holothuria arguinensis populations in Ria Formosa (southern Portugal). SPC Bêchede-mer Information Bulletin, 33, 44-48.

González-Wangüemert, M., \& Domínguez-Godino, J. A. (2017). Assessment of Holothuria arguinensis genetic patterns of breeders and larvae from aquaculture production. Mazatlan, Mexico: Latino American and Caribbean Aquaculture Society Congress, 7-10 November 2017.

González-Wangüemert, M., Domínguez-Godino, J. A., \& Cánovas, F. (2018). The fast development of sea cucumber fisheries in the Mediterranean and NE Atlantic waters: From a new marine resource to its over-exploitation. Ocean and Coastal Management, 151, 165177. https://doi.org/10.1016/j.ocecoaman.2017.10.002

González-Wangüemert, M., Valente, S., \& Aydin, M. (2015). Effects of fishery protection on biometry and genetic structure of two target sea cucumber species from the Mediterranean Sea. Hydrobiologia, 743, 65-74. https://doi.org/10.1007/s10750-014-2006-2

González-Wangüemert, M., Valente, S., Henriques, F., DomínguezGodino, J. A., \& Serrão, E. A. (2016). Setting preliminary biometric baselines for new target sea cucumbers species of the NE Atlantic and Mediterranean fisheries. Fisheries Research, 179, 57-66. https:// doi.org/10.1016/j.fishres.2016.02.008

Gressler, V., Yokoya, N. S., Fujii, M. T., Colepicolo, P., Mancini Filho, J., Torres, R. P., \& Pinto, E. (2010). Lipid, fatty acid, protein, amino acid and ash contents in four Brazilian red algae species. Food Chemistry, 120(2), 585-590. https://doi.org/10.1016/j.foodc hem.2009.10.028

Hammond, L. (1983). Nutrition of deposit-feeding holothuroids and echinoids (Echinodermata) from a shallow reef lagoon, Discovery Bay, Jamaica. Marine Ecology Progress Series, 10, 297-305. https://doi. org/10.3354/meps010297

Kjeldahl, J. (1883). Neue Methods zur Bestimmung des Stickstoffs in Organischen Korpern, Z. Analytical Chemistry, 22, 366-382.
Krishnan, S. (1968). Histochemical studies on reproductive and nutritional cycles of the holothurian, Holothuria scabra. Marine Biology, 2, 54-65.

Kruskal, W., \& Wallis, W. (1952). Use of ranks in one-criterion variance analysis. Journal of the American Statistical Association, 47(260), 583621. https://doi.org/10.1080/01621459.1952.10483441

Lepage, G., \& Roy, C. C. (1984). Improved recovery of fatty acid through direct transesterification without prior extraction or purification. Journal of Lipid Research, 25, 1391-1396.

Liu, X., Zhou, Y., Yang, H., \& Ru, S. (2013). Eelgrass detritus as a food source for the sea cucumber Apostichopus japonicus Selenka (Echinidermata: Holothuroidea) in coastal waters of north China: An experimental study in flow-through systems. PLoS ONE, 8(3), e58293. https://doi. org/10.1371/journal.pone.0058293

Liu, Y., Dong, S., Tian, X., Wang, F., \& Gao, Q. (2010). The effect of different macroalgae on the growth of sea cucumbers (Apostichopus japonicus Selenka). Aquaculture Research, 41(11), e881-e885. https://doi. org/10.1111/j.1365-2109.2010.02582.x

Liu, Y. Y., Li, F. X., Song, B. X., Sun, H. L., Zhang, X. L., \& Gu, B. X. (1996). Study on aestivation habit of sea cucumber Apostichopus japonicus Sleneka: Ecological characteristics of aestivation. Journal of Fisheries Sciences, 3, 41-48. (in Chinese with English abstract).

Maggi, C., \& González-Wangüemert, M. (2015). Genetic differentiation among Parastichopus regalis populations from Western Mediterranean Sea: Potential effects of its fishery and current connectivity. Mediterranean Marine Sciences, 16, 489-501. https://doi. org/10.12681/mms.1020

Marquet, N., Conand, C., Power, D. M., Canário, A. V., \& GonzálezWangüemert, M. (2017). Sea cucumbers, Holothuria arguinensis and H. mammata, from the southern Iberian Peninsula: Variation in reproductive activity between populations from different habitats. Fisheries Research, 191, 120-130. https://doi.org/10.1016/j.fishr es.2017.03.007

Meziane, T., \& Tsuchiya, M. (2000). Fatty acids as tracers of organic matter in the sediment and food web of a mangrove/intertidal flat ecosystem, Okinawa, Japan. Marine Ecology Progress Series, 200, 49-57. https://doi.org/10.3354/meps200049

Milović, S., Kundaković, T., Mačić, V., Stanković, J. A., Grozdanić, N. Đuričić, I., ... Stanojković, T. (2017). Anti $\alpha$-glucosidase, antitumour, antioxidative, antimicrobial activity, nutritive and health protective potential of some seaweeds from the Adriatic coast of Montenegro. FARMACIA, 65(5), 731-740.

Navarro, P. G., García-Sanz, S., \& Tuya, F. (2014). Contrasting displacement of the sea cucumber Holothuria arguinensis between adjacent nearshore habitats. Journal of Experimental Marine Biology and Ecology, 453, 123-130. https://doi.org/10.1016/j.jembe.2014.01.008

Olaya-Restrepo, J., Erzini, K., \& González-Wangüemert, M. (2018). Estimation of growth parameters for the exploited sea cucumber Holothuria arguinensis from South Portugal. Fishery Bulletin, 116(1), 1-8.

Pereira, H., Barreira, L., Figueiredo, F., Custódio, L., Vizetto-Duarte, C., Polo, C., ... Varela, J. (2012). Polyunsaturated fatty acids of marine macroalgae: Potential for nutritional and pharmaceutical applications. Marine Drugs, 10, 1920-1935. https://doi.org/10.3390/md100 91920

Pohlert, T. (2014). The pairwise multiple comparison of mean ranks package (PMCMR). R package, 2004-2006.

Purcell, S. (2010). Managing sea cucumber fisheries with an ecosystem approach. FAO Fisheries and Aquaculture Technical Paper No. 520. Rome, Italy: FAO.

Purcell, S. W., Mercier, A., Conand, C., Hamel, J. F., Toral-Granda, M. V., Lovatelli, A., \& Uthicke, S. (2013). Sea cucumber fisheries: Global analysis of stocks, management measures and drivers of overfishing. Fish and Fisheries, 14, 34-59. https://doi. org/10.1111/j.1467-2979.2011.00443.x 
Purcell, S. W., Samyn, Y., \& Conand, C. (2012). Commercially important sea cucumbers of the world. FAO Species Catalogue for Fishery Purposes. No. 6. (pp. 150). Rome, Italy: FAO.

R Core Team. (2013). R: A language and environment for statistical computing. Vienna, Austria: R Foundation for Statistical Computing. http:// www.R-project.org/

Rakaj, A., Fianchini, A., Boncagni, P., Lovatelli, A., Scardi, M., \& Cataudella, S. (2017). First artificial reproduction of Holothuria polii: a new candidate for aquaculture. Aquaculture Europe 2017 (Dubrovnik, Croatia), 17-20, 2017.

Rakaj, A., Fianchini, A., Boncagni, P., Lovatelli, A., Scardi, M., \& Cataudella, S. (2018). Spawning and rearing of Holothuria tubulosa: A new candidate for aquaculture in the Mediterranean region. Aquaculture Research, 49(1), 557-568. https://doi.org/10.1111/are.13487

Roberts, D., Gebruk, A., Levin, V., \& Manship, B. (2003). Feeding and digestive strategies in deposit-feeding holothurians. Oceanography and Marine Biology: an Annual Review, 38, 257.

Sèbe, G., Pardon, P., Pichavant, F., Grelier, S., \& De Jéso, B. (2004). An investigation into the use of eelgrass (Zostera noltii) for removal of cupric ions from dilute aqueous solutions. Separation and Purification Technology, 38(2), 121-127. https://doi.org/10.1016/j. seppur.2003.10.009

Seo, J. Y., Shin, I. S., \& Lee, S. M. (2011). Effect of dietary inclusion of various plant ingredients as an alternative for Sargassum thunbergii on growth and body composition of juvenile sea cucumber Apostichopus japonicus. Aquaculture Nutrition, 17(5), 549-556. https ://doi.org/10.1111/j.1365-2095.2010.00849.x

Sewell, M. A. (1990). Aspects of the ecology of Stichopus mollis (Echinodermata: Holothuroidea) in north-eastern New Zealand. New Zealand Journal of Marine and Freshwater Research, 24, 97-103. https ://doi.org/10.1080/00288330.1990.9516405

Siegenthaler, A., Cánovas, F., \& González-Wangüemert, M. (2015). Spatial distribution patterns and movements of Holothuria arguinensis in the Ria Formosa (Portugal). Journal of Sea Research, 102, 33-40. https:// doi.org/10.1016/j.seares.2015.04.003

Song, X., Xu, Q., Zhou, Y., Lin, C., \& Yang, H. (2017). Growth, feed utilization and energy budgets of the sea cucumber Apostichopus japonicus with different diets containing the green tide macroalgae Chaetomorpha linum and the seagrass Zostera marina. Aquaculture, 470, 157-163. https://doi.org/10.1016/j.aquaculture.2016.12.035

Uthicke, S. (1999). Sediment bioturbation and impact of feeding activity of Holothuria (Halodeima) atra and Stichopus chloronotus, two sediment feeding holothurians, at Lizard Island. Bulletin of Marine Science, 64, 129-141.

Wen, B., Gao, Q. F., Dong, S. L., Hou, Y. R., Yu, H. B., \& Li, W. D. (2016). Effects of different feed ingredients on growth, fatty acid profiles, lipid peroxidation and aminotransferases activities of sea cucumber Apostichopus japonicus (Selenka). Aquaculture, 454, 176-183. https:// doi.org/10.1016/j.aquaculture.2015.12.027

Wong, W. H., Gao, Q. F., Cheung, S. G., \& Shin, P. K. (2008). Field observations on correlation of fatty acid profiles between suspended particulate matter and green-lipped mussels in subtropical waters of
Hong Kong. Marine Pollution Bulletin, 57(6-12), 662-671. https://doi. org/10.1016/j.marpolbul.2007.12.019

Xia, S., Yang, H., Li, Y., Liu, S., Zhou, Y., \& Zhang, L. (2012). Effects of different seaweed diets on growth, digestibility, and ammonia-nitrogen production of the sea cucumber Apostichopus japonicus (Selenka). Aquaculture, 338, 304-308. https://doi.org/10.1016/j. aquaculture.2012.01.010

Yamanouchi, T. (1939). Ecological and physiological studies on the holothurians in the coral reef of palao islands. Palao Tropical Biological Station Studies, Report, 4, 603-636.

Yamanouti, T. (1939). Ecological and physiological studies on the holothurians in the coral reef of Palao Islands. PalaoTropical Biology, 4, 603-636.

Yanagisawa, T. (1998). Aspects of the biology and culture of the sea cucumber. In S. De Silva (Ed.), Tropical mariculture (pp. 291-308). London, UK: Academic Press.

Yang, H., Yuan, X., Zhou, Y., Mao, Y., Zhang, T., \& Liu, Y. (2005). Effects of body size and water temperature on food consumption and growth in the sea cucumber Apostichopus japonicus (Selenka) with special reference to aestivation. Aquaculture Research, 36(11), 1085-1092. https ://doi.org/10.1111/j.1365-2109.2005.01325.x

Yingst, J. Y. (1976). The utilization of organic matter in shallow marine sediments by an epibenthic deposit-feeding holothurian. Journal of Experimental Marine Biology and Ecology, 23, 55-69. https://doi. org/10.1016/0022-0981(76)90085-X

Yuan, X., Yang, H., Zhou, Y., Mao, Y., Zhang, T., \& Liu, Y. (2006). The influence of diets containing dried bivalve feces and/or powdered algae on growth and energy distribution in sea cucumber Apostichopus japonicus (Selenka) (Echinodermata: Holothuroidea). Aquaculture, 256, 457-467. https://doi.org/10.1016/j.aquaculture.2006.01.029

Zamora, L. N., \& Jeffs, A. G. (2011). Feeding, selection, digestion and absorption of the organic matter from mussel waste by juveniles of the deposit-feeding sea cucumber, Australostichopus mollis. Aquaculture, 317(1), 223-228. https://doi.org/10.1016/j.aquac ulture.2011.04.011

Zamora, L. N., \& Jeffs, A. G. (2012). The ability of the deposit-feeding sea cucumber Australostichopus mollis to use natural variation in the biodeposits beneath mussel farms. Aquaculture, 326, 116-122. https ://doi.org/10.1016/j.aquaculture.2011.11.015

Zhu, J., Liu, H., Leng, K., Qu, K., Wang, S., Xue, Z., \& Sun, Y. (2007). Studies on the effects of some common diets on the growth of Apostichopus japonicus. Marine Fisheries Research, 25, 48-53 (in Chinese, with English abstract).

How to cite this article: Domínguez-Godino JA, Santos TF, Pereira H, Custódio L, González-Wangüemert M. Seagrass debris as potential food source to enhance Holothuria arguinensis' growth in aquaculture. Aquac Res. 2020;51:14871499. https://doi.org/10.1111/are.14495 